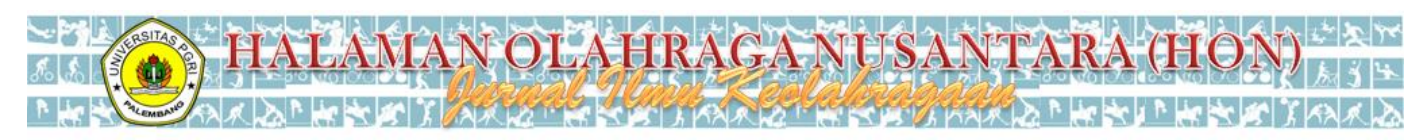

Volume 4, No 1

ISSN 2614-2775 (Print)

Tahun 2021

ISSN 2621-8143 (Online)

\title{
GAYA MENGAJAR DAN PERCAYA DIRI TERHADAP HASIL BELAJAR SHOOTING SEPAKBOLA
}

\author{
A Apri Satriawan Chan ${ }^{1}$, Dede Dwiansyah Putra ${ }^{2}$, Ardo Okilanda ${ }^{3}$ \\ STKIP Kusuma Negara ${ }^{1}$, Universitas Negeri Jakarta ${ }^{2,3}$, Indonesia \\ satriawanchan@gmail.com, dededwiansyahputra@gmail.com, ardo.oku@gmail.com
}

\begin{abstract}
Abstrak
Penelitian ini bertujuan untuk mengetahui pengaruh gaya mengajar inklusi dan gaya mengajar latihan serta percaya diri terhadap hasil belajar shooting dalam permainan sepakbola. Penelitian ini dilakukan pada siswa SMA Negeri 2 Padang.Jenis penelitian ini adalah eksperimen menggunakan rancangan treatment by level $2 \times 2$. Populasi penelitian ini adalah seluruh Siswa SMA Negeri 2 Padang yang berjumlah 787siswa. Penetapan sampel menggunakan teknik simple random sampling yaitu menetapkan siswa kelas X MIA 1 dan X MIA 2 yang berjumlah 64siswa.Sampel perlakuan dalam penelitian ini adalah 36 orang siswa setelah dilakukan pembagian kelompok $27 \%$ percaya diri tinggi dan $27 \%$ percaya diri rendah. Data yang diperoleh kemudian dianalisis dengan analisis varians (ANAVA) dua jalur. dan selanjutnya dilanjutkan dengan uji Tukey pada tingkat signifikansi $\alpha=0$, 05. Hasil penelitian ini menunjukkan bahwa (1). Hasil belajarshooting dalam permainan sepakbola pada perlakuan gaya mengajar inklusi $\left(\mathrm{A}_{1}\right)$ lebih tinggi dari hasil gaya mengajar latihan $\left(\mathrm{A}_{2}\right)$. (2). Terdapat pengaruh interaksi antara gaya mengajar (A) dan percaya diri (B)terhadap hasil belajarpassing dalam permainan sepakbola. (3). Hasil belajarshooting dalam permainan sepakbola pada perlakuangaya mengajar inklusi percaya diri tinggi $\left(\mathrm{A}_{1} \mathrm{~B}_{1}\right)$ lebih tinggi dari hasilgaya mengajar latihanpercaya diri tinggi $\left(\mathrm{A}_{2} \mathrm{~B}_{1}\right)$. (4). Hasil belajar shooting dalam permainan sepakbola pada perlakuangaya mengajar inklusi percaya diri rendah $\left(\mathrm{A}_{1} \mathrm{~B}_{2}\right)$ lebih rendah dari hasil gaya mengajar latihan percaya diri rendah $\left(\mathrm{A}_{2} \mathrm{~B}_{2}\right)$.
\end{abstract}

Kata kunci : Gaya Mengajar Inklusi dan Gaya Mengajar Latihan, Percaya Diri, Hasil BelajarShooting Dalam Permainan Sepakbola.

\section{STYLE OF TEACHING AND CONFIDENCE LEARNING OUTCOMES IN SHOOTING GAME FOOTBALL}

\begin{abstract}
The purpose ofthis study wasto determine the effect of inclusion of teaching styles and teaching styles of exercise and confidenton learning outcomes shooting in the game of football. This research was conducted studentat theSenior High School2 Padang. This type of research is experimental design was used treatment by level $2 x 2$. The study population was all students of Senior High School 2 Padang, amounting to 787 students .Determination of the sample using simple random sampling techniqueis to set the class $X 1$ and XMIA MIA2 totaling 64 students. Sample streated in this study were 36 students after the division of the group27\% confidence high and 27\% lower confidence. The data obtained and analyzed byanalysis of variance(ANAVA) and twolanes. And subsequently followed by Tukey's test at a significance level $\alpha=0$, 05. The results showed that(1). Learning outcomes shooting in the game of football in the treatment teaching style
\end{abstract}

Correspondenceauthor: A Apri Satriawan Chan, STKIP Kusuma Negara, Indonesia. E-Mail: satriawanchan@gmail.com

\section{(c) (i) ()}

Jurnal HalamanOlahraga Nusantara licensed under a Creative Commons Attribution-ShareAlike 4.0 International License. 
inclusions $\left(A_{1}\right)$ is high erthan the results of the exercise teaching style $\left(A_{2}\right) .(2)$. There is an interaction effect between teaching style $(A)$ and confidence $(B)$ on learning out comes passing in the game of football. (3). Learning outcomes shooting in the game of football in the treatment of inclusion confident style of teachingis high $\left(A_{1} B_{1}\right)$ higher than the confident style oft eaching and training high $\left(A_{2} B_{1}\right)$. (4). Results of learning outcomes shooting in the game of football in the treatment of inclusion confident style of teaching is low $\left(A_{1} B_{2}\right)$ lower than the confident

Key words: Teaching Style Inclusion and Exercise, Confidence, Learning Outcomes Shooting In Football

\section{PENDAHULUAN}

Olahraga yang paling banyak menguasai kehidupan sehari-hari yaitu sepakbola baik dari sisi kecintaan dan penggemar yang fanatik, memiliki daya serap yang cukup banyak dalam kehidupan, (Ardo Okilanda, Firmansyah Dlis, Hidayat Humaid, 2020). Sepakbola adalah salah satu permainan yang sangat digemari di sekolah- sekolah yang ada di Indonesia, tidak terkecuali di daerah Padang, Sumatera Barat. Sepakbola adalah salah satu permainan bola besar yang disajikan dalam kurikulum pendidikan jasmani olahraga dan kesehatan di Sekolah Menengah Atas (SMA), sehingga sepak bola dapat digunakan sebagai media atau sarana dalam mengajar pendidikan jasmani olahraga dan kesehatan yang menggunkan aktivitas fisik sebagai media untuk pencapaian tujuan pendidikan (Adam, 2007).

Masalah-masalah umum yang banyak sering di temui dalam pendidikan di jenjang SMA seperti sarana dan prasarana yang tidak lengkap, serta kualitas dan kuantitas sarana dan prasarana pendidikan jasmani olahraga dan kesehatan tidak sebanding dengan jumlah siswa yang ada di sekolah. Akibatnya waktu belajar pendidikan jasmani olahraga dan kesehatan lebih banyak dilakukan untuk menunggu giliran di bandingkan dengan aktivitas olahraga yang di lakukan. Akibat yang lebih jauh adalah aktifitas gerak anak menjadi berkurang dan tidak dapat di lakukan proses aktivitas gerak.

Gaya mengajar yang menempatkan siswa sebagai subjek mengajar dengan iteraksi belajar dua arah atau lebih, dari guru ke siswa, dari siswa ke guru, dan dari siswa ke siswa yang lain sangat diperlikan agar kemampuan anak dapat dikembangkan secara optimal melalui pendidikan jasmani, model mengajar 
tersebut menempatkan siswa sebagai subjek mengajar dan mengambil peran dan tanggung jawab yang lebih besar dalam proses mengajar pendidikan jasmani

Gaya mengajar merupakan salah satu cara untuk mengembangkan pola gerak anak melalui permainan sepakbola. Dalam hal ini gaya mengajar yang bisa diterapkan dalam pembelajaran adalah gaya mengajar Latihan dan gaya mengajar Inklusi. Gaya mengajar latihan siswa diberikan waktu untuk melaksanakan tugas secara perorangan, sedangkan guru memberi umpan balik kepada semua siswa secara perorangan. Disini guru bertanggung jawab menentukan tujuan pengajaran, memilih aktivitas dan menetapkan tata urut kegiatan untuk mencapai tujuan pengajaran.

Belajar merupakan suatu proses yang berlangsung sepanjang hayat. Hampir semua kecakapan, keterampilan pengetahuan, kebiasan, kegemaran, dan sikap manusia terbentuk, dimodifikasin dan berkembang karena belajar.Belajar merupakan komponen ilmu pendidikan yang berkenaan dengan tujuan dan bahan acuan interaksi.baik yang bersifat eksplisit maupun implisit (tersembunyi). Teoriteori yang dikembangkan dalam komponen ini meliputi antara lain teori tentang tujuan pendidikan, organisasi kurikulum, isi kurikulum dan modul-modul pengembangan kurikulum. Kegiatan atau tingkah laku belajar terdiri dari kegiatan psikhis dan fisisyang saling bekerjasama secara terpadu (A Coker, 2004).

\section{Shooting Sepakbola}

Teknik menendang bola merupakan teknik dasar yang utama dalam permainan sepak bola, oleh karena itu harus dikuasai oleh setiap siswa. Kemampuan menendang bola secara terarah bertambah penting artinya apabila lawan bermain dengan sistem bertahan, sehingga ruang gerak sempit untuk dapat ditembus salah satunya dengan umpan terobosan. Kemampuan menendang dilihat dari perkenaannya bagian kaki ke bola dapat dibedakan beberapa macam, yaitu menendang dengan kaki bagian dalam,kaki bagian luar, punggung kaki, dan punggung kaki bagian dalam (Luxbacher, 2013).

Tujuan menendang bola adalah untuk mengumpan, menembak ke gawang dan menyapu untuk menggagalkan serangan lawan. Teknik menendang bola 
dengan kaki bagian dalam : Awalan lurus dengan bola, kaki tumpu diletakkan di samping bola dengan jari kaki menghadap ke depan dan lutut sedikit ditekuk, badan condong kedepan sehingga hidung, lutut dan ujung kaki satu garis. Kaki sepak di putar keluar pada pangkal paha sehingga kaki sepak membentuk sudut 90 derajat dengan kaki tumpu. Daerah perkenaan kaki dengan bola pada pergelangan kaki agak ke depan, seang sentuhan kaki (Koger, 2007).

Permainan sepakbola sangat memperlukan siswa untuk memiliki keterampilan menendang bola yang baik, untuk itu sangat penting sekali mempelajarinya, hal tersebut seperti yang dikemukakan oleh Joseph A. Luxbacher bahwa: Keterampilan untuk menendang bola membentuk jalinan vital yang menghubungkan kesebelas siswa ke dalam satu unit yang berfungsi lebih baik daripada bagian-bagiannya. Pengusaan keterampilan yang baik merupakan salah satu persyaratan yang harus dimiliki untuk menjadi pemain sepakbola yang berprestasi (Okilanda, 2017). Selanjutnya dikatakan pula : Ketepatan, langkah dan waktu pelepasan bola merupakan bagian yang penting dari kombinasi pengoperan bola yang berhasil. Lebih lanjut beliau mengatakan bahwa : Keterampilan menendang bola yang tidak baik akan mengakibatkan lepasnya bola dari anda dan membuang-buang kesempatan untuk menciptakan gol (Al-Hadiqie, 2013).

Kemampuan menembak (shooting) harus dilatih dengan sebaik mungkin, hal ini merupakan eksekusi terakhir dari proses penyerangan. Latihan shooting sebaiknya dimulai dari urutan yang paling sederhana sampai urutan yang rumit. Cara yang tepat untuk mengembangkan teknik menembak (shooting) adalah melatih tendangan sebanyak mungkin dengan menggunakan teknik yang benar. Jadi bila ingin mendapatkan kemampuan menembak (shooting) yang baik, siswa sepakbola harus diberikan kesempatan untuk menendang ke gawang sebanyak mungkin pada sesi latihan menembak (shooting). Yang dipertegas oleh Mielke "siswa akan semakin bisa menjalankan kemampuan menembak (shooting) di dalam pertandingan dan memanfaatkan peluang dengan baik jika semakin banyak berlatih menggunakan situasi yang berbeda (Okilanda, Ardo., Dony, Pria Roma., \& Putra, 2020) 
Berdasarkan hal tersebut proses pelaksanaan kemampuan shooting yang baik memiliki tahapan-tahapan pelaksanaan, letakkan kaki tumpu disamping bola lalu tarik kaki yang akan digunakan untuk menendang kebelakang.Fokuskan perhatian pada bola dan perkenaan bola dengan kaki menggunakan kaki bagian dalam maupun punggung kaki. semakin baik pelaksanaan shooting seorang siswa maka semakin baik hasil dari shooting tersebut. Secara keseluruhan drill pelaksanaan shooting, dimana pandangan serta keseimbangan focus terhadap bola yang bergerak ataupun diam secara keseluruhan sebelum perkenaan kaki dengan bola.

\section{Gaya Mengajar Inclusion}

Mosston menggambarkan konsep gaya inclusion memperkenalkan berbagai tingkat tugas. The defining characteristic of the inclusion style is that learning with varying degree of skill participate in same task by selecting a level of difficulty at which they perform. Gaya inclusion memberikan konsep tugas yang sama dengan tingkatan yang berbeda-beda. Dalam gaya ini siswa dituntut untuk meningkatkan penampilanya dalam setiap bentuk meteri latihan (Critchell, 2003).

Konsep desain tugas yang diberikan Guru pada pra-pertemuan yang berbeda tingkatnya. Contoh seperti berikut; memegang tali diantara dua siswa yang berdiri dengan ketinggian mulai dari lantai dan tanya siswa anda untuk mengambil beberapa langkah-langkah serta melompat di atasnya. Beri kesempatan kepada seluruh siswa. Lakukan dengan berulang kali, lalu naikan beberapa inci kemudian ulangi. Apakah semua sukses? Setelah tali dinaikan beberapa kali, tentu ada yang bisa dan ada yang tidak sukses melakukannya. Inilah yang melandasi konsep dari gaya inclusion.

Gaya inclusion adalah suatu gaya pembelajaran yang digunakan oleh Guru, dengan cara menyajikan materi latihan secara rinci dan menawarkan tingkat-tingkat kesulitan yang berbeda secara berurutan, yang bertujuan agar siswa kreatif dan mendapatkan kemudahan dalam mempelajari suatu keterampilan gerak, juga siswa diberi kebebasan untuk memilih dan menentukan pada tingkat kesulitan mana untuk memulai belajar suatu gerakan. Serta diberi kebebasan dan 
keleluasaan pula untuk menentukan berapa kali siswa harus mengulangi gerakan, dalam mempelajari suatu teknik gerakan dalam setiap pertemuan.

Gaya inclusion dikembangkan berdasar konsep belajar yang berpusat pada peserta didik dan kurikulum yang dikembangkan sesuai dengan kebutuhan perorangan serta peserta didik memperoleh kesempatan untuk belajar sesuai dengan tempo dan kemampuan masing- masing. Namun demikian, tidak ada gaya mengajar yang baku dalam proses pembelajaran dan tidak ada yang paling baik karena setiap gaya mengajar mempunyai karakteristik dan tujuan yang berbeda antara satu gaya mengajar dengan gaya mengajar yang lain. Gaya mengajar sekali waktu ditekankan pada guru sebagai pusat pembelajaran, dan sekali waktu berpusat pada peserta didik.

\section{Gaya Mengajar Latihan}

Gaya latihan untuk membentuk realitas baru, yang menawarkan kondisi baru untuk belajar, dan mencapai tujuan yang berbeda dari gaya Komando. Hubungan gaya praktek terjadi karena keputusan-keputusan tertentu untuk beralih dari guru kepada siswa. Pergeseran, di mana untuk membuat keputusan tentang apa, kapan, untuk menciptakan hubungan baru antara guru dan siswa, antara mahasiswa dan tugas-tugas, dan antara peserta didik sendiri. Di setiap bidang, gaya praktek adalah perilaku yang dominan: orang secara individu tugas-tugas praktis dan menerima umpan balik. Ini tonggak pengajaran dan pembelajaran dapat menekankan salah satu atribut di sepanjang saluran pengembangan kinerja. Akibatnya, citra kelas untuk perilaku ini adalah tidak unik. Walaupun ada variasi lebih dalam gambar kelas gaya ini sebagian besar gaya, distribusi pilihan untuk variasi ini adalah anatomi gaya praktek.

Untuk menentukan pendekatan terhadap pengembangan pengajaran apapun dan peristiwa belajar yang diperlukan untuk mengidentifikasi keputusan spesifik yang dibuat oleh guru dan siswa dan nominal di konten. Gaya latihan dalam anatomi gaya ini, peran guru adalah untuk membuat semua keputusan dalam efek dari pra-dan pasca-set dampak. Pada set dampak, keputusan guru untuk menggeser sembilan siswa, sehingga peran siswa adalah membuat sembilan 
keputusan saat melakukan tugas yang dirancang oleh guru.Guru harus belajar untuk menggeser keputusan-waktu dan menahan diri dari memberikan perintah untuk setiap tugas, gerakan, atau kegiatan siswa memiliki kesempatan untuk memulai praktik, untuk memulai interaksi dengan tugas sendiri, dan untuk memulai dan belajar untuk membuat sembilan keputusan dalam parameter, (Syahrastani, 2010).

\section{Percaya Diri}

Dalam upaya pencapaian prestasi tinggi, keadaan fisik maupun mental siswa harus dalam kondisi yang baik. Ini sesuai dengan pendapat Desmita yang menegaskan bahwa prestasi yang tinggi hanya dapat dicapai dengan mobilitas total seluruh energi dalam hal ini peranan kesiapan mental akan ikut menentukan.Percaya diri atau self-confidence merupakan modal utama seorang siswa untuk dapat maju, karena pencapaian prestasi yang tinggi dan pemecahan rekor siswa itu sendiri harus dimulai dengan percaya bahwa ia dapat dan sanggup melampaui prestasi yang pernah dicapainya.Tanpa memiliki penuh rasa percaya diri, siswa tidak akan dapat mencapai prestasi, karena ada saling hubungan antara motif berprestasi dan percaya diri.

\section{METODE}

Metode yang digunakan dalam penelitian ini adalah metode eksperimen lapangan. Sebagaimana dikemukakan Sugiono bahwa, dalam penelitian ini ada perlakuan (Treatment), dengan demikian metode penelitian eksperimen dapat diartikan sebagai metode penelitian yang digunakan untuk mencari pengaruh perlakuan tertentu terhadap yang lain dalam kondisi yang terkendalikan (Sugiyono, 2010).

Dalam penelitian ini dilibatkan tiga variabel, yakni : (1) Variabel bebas adalah gaya mengajar inklusi dan gaya mengajar latihan (2) Variabel terikat adalah hasil belajarshootingdalam permainan sepakbola, dan (3) Variabel atribut yaitu percaya diri. Desain penelitian atau rancangan penelitian adalah rencana dan struktur penyelidikan yang disusun sedemikan rupa sehingga peneliti akan memperoleh jawaban untuk pertanyaan-pertanyaan penelitiannya. 
Desain penelitian ini menggunakan rancangan treatment by level $2 \times 2$. Rancangan treatment adalah unit-unit eksperimen ke dalam sel sedemikan rupa secara acak, sehingga unit-unit eksperimen dalam setiap sel relatif bersifat homogen. Secara visual desain penelitian ini dapat di gambarkan sebagai berikut :

Tabel 1.Rancangan Treatment By Level 2 × 2

\begin{tabular}{lll} 
Gercaya Diri & \multicolumn{1}{c}{$\begin{array}{c}\text { Gnclusion } \\
\left(\mathbf{A}_{1}\right)\end{array}$} & $\begin{array}{c}\text { Latihan } \\
\left(\mathbf{A}_{2}\right)\end{array}$ \\
\hline Tinggi (B1) & A1B1 & A2B1 \\
\hline Rendah (B2) & A1B2 & A2B2
\end{tabular}

Total

Populasi adalah semua subyek yang diteliti (Suharno, 2000). Berdasarkan pendapat diatas maka populasinya adalah semua siswadi SMA Negeri 2 Kota Padang dengan jumlah 787 orang siswa.Pengambilan sampel dilakukan dengan teknik simple random sampling, yaitu penentuan anggota sampel dilakukan secara acak tanpa memperhatikan strata yang ada dalam suatu populasi, (Uno, 2008). Untuk populasi terjangkau yang dapat diteliti, yaitu kelas X karena di SMA Negeri 2 Padang yang berjumlah 288. Kelas XI mengikuti proses belajar tambahan sampai dengan pukul 16.00 sedangkan untuk kelas XII lebih difokuskan untuk persiapan UN (Ujian Nasional) tahun 2015. Berdasarkan hal tersebut maka sampel dalam penelitian ini ditetapkan setelah mengacak dalam populasi terjangkau pada kelas X yaitu kelas X-MIA 1 dan X-MIA 2 sebanyak 64siswa.

Untuk menentukan kelompok siswa yang memiliki percaya diritinggi dan percaya diri rendah dilakukan dengan menyeleksi $27 \%$ jumlah data skor tertinggi dan $27 \%$ skor terendah. Dari perhitungan tersebut didapatkan 27\% dari tiap-tiap kelompok untuk skor tertinggi dan terendah adalah $27 \%$ x $64=17.28$ dibulatkan menjadi 18 orang. Jadi 18 orang dengan skor tertinggi digolongkan dalam kelompok siswayang memiliki motivasi berprestasi tinggi, sedangkan 18 orang 


\section{OLAHRAGA}

Jendral A. Yani Street Lorong Gotong Royong 9/10 Ul Palembang South Sumatera

dengan skor terendah digolongkan dalam kelompok siswayang memiliki motivasi berprestasi rendah dari masing-masing kelompok.

\section{HASIL}

Untuk menguji hipotesis, data hasil belajar stut diolah dengan menggunakan teknik analisis statistik, yaitu analisis varians (ANAVA) dua jalan. Sebelum data dianalisis, maka terlebih dahulu dilakukan uji persyaratan Anava, yaitu : (1) Uji normalitas,dan (2) Uji homogenitas. Uji normalitas dilakukan pada semua kelompok yang akan dibandingkan dengan menggunakan uji Lilliefors. Hasil pengujian tersebut menunjukkan bahwa harga Litung $_{\text {untuk semua kelompok }}$ lebih kecil daripada $\mathrm{L}_{\text {tabel. }}$

Tabel 3. Rangkuman Hasil Uji Normalitas Populasi

\begin{tabular}{|c|c|c|c|c|}
\hline Kelompok & $\mathbf{N}$ & Lhitung & $\begin{array}{c}\mathbf{L}_{\text {tabel }} \\
\boldsymbol{\alpha}=\mathbf{0 , 0 5}\end{array}$ & Kesimpulan \\
\hline 1 & 18 & 0,1159 & 0,2 & Normal \\
2 & 18 & 0,1419 & 0,2 & Normal \\
3 & 18 & 0,0799 & 0,2 & Normal \\
4 & 18 & 0,1143 & 0,2 & Normal \\
5 & 9 & 0,1417 & 0,271 & Normal \\
6 & 9 & 0,1004 & 0,271 & Normal \\
7 & 9 & 0,1190 & 0,271 & Normal \\
8 & 9 & 0,1169 & 0,271 & Normal \\
\hline
\end{tabular}

Keterangan :

Kelompok $1=$ Kelompok siswa yang diajar dengan gaya mengajar Inklusi secara keseluruhan

Kelompok 2 = Kelompok siswa yang diajar dengan gaya mengajar latihan secara keseluruhan

Kelompok $3=$ Kelompok siswa yang memiliki percaya diri tinggi secara keseluruhan

Kelompok $4=$ Kelompok siswa yang memiliki percaya diri rendah secara keseluruhan

Kelompok $5=$ Kelompok siswa yang memiliki percaya diri tinggi, diajar dengan gaya mengajar inklusi

Kelompok $6=$ Kelompok siswa yang memiliki percaya diri tinggi, diajar dengan gaya mengajar latihan

Kelompok $7=$ Kelompok siswa yang memiliki percaya diri rendah, diajar 
dengan gaya mengajar inklusi

Kelompok $8=$ Kelompok siswa yang memiliki percaya diri rendah, diajar dengan gaya mengajar latihan

Uji homogenitas dilakukan terhadap data skor hasil belajar shooting masing - masing kelompok perlakukan dan kelompok perlakuan secara keseluruhan. Uji homogenitas yang digunakan dalam penelitian ini adalah uji Bartlett dengan taraf signifikansi $\boldsymbol{\alpha}=0,05$. Ringkasan hasil perhitungan uji homogenitas varians masing-masing kelompok tampak pada Tabel di bawah ini.

Tabel 4.Ringkasan Hasil Perhitungan Uji Homogenitas Varians Masingmasing Kelompok Perlakuan dengan Uji Bartlett

\begin{tabular}{|c|c|c|c|c|c|}
\hline Kelompok & Varians & $\begin{array}{c}\text { Varians } \\
\text { Gabungan }\end{array}$ & $\chi^{\mathbf{2} \text { hitung }}$ & $\begin{array}{c}\chi^{\mathbf{2}} \text { tabel } \\
\boldsymbol{\alpha}=\mathbf{0 . 0 5}\end{array}$ & Kesimpulan \\
\hline 1. & 1,9365 & & & & \\
2. & 2,4381 & 2,1410 & 0,2180 & 7,81 & Homogen \\
3. & 1,8559 & & & & \\
4. & 2,3333 & & & & \\
\hline
\end{tabular}

Dari hasil perhitungan uji homogenitas seperti tampak pada tabel di atas, didapat harga Chikuadrat sebesar $\left(\chi_{\mathrm{h}}^{2}=0,2180\right)$ untuk seluruh kelompok sampel, lebih kecil daripada Chikuadrat tabel $\left(\chi_{\mathrm{t}}^{2}=7,81\right)$.Dengan demikian dapat disimpulkan bahwa sampel penelitian berasal dari populasi berdistribusi homogen (Kadir, 2010)

Tabel 5. Rangkuman Uji Homogenitas Secara Keseluruhan

\begin{tabular}{|c|c|c|c|c|}
\hline Kelompok & Varians & $\mathbf{F}_{\text {hitung }}$ & $\begin{array}{c}\mathbf{F}_{\mathbf{t}} \\
\alpha=0.05\end{array}$ & Kesimpulan \\
\hline $\begin{array}{l}\mathbf{A}_{1} \\
\mathbf{A}_{2}\end{array}$ & $\begin{array}{c}12,22 \\
5,44 \\
\end{array}$ & 2,25 & 2,27 & Homogen \\
\hline $\begin{array}{l}\mathbf{B}_{1} \\
\mathbf{B}_{2}\end{array}$ & $\begin{array}{l}9,28 \\
4,45\end{array}$ & 2,09 & 2,27 & Homogen \\
\hline $\begin{array}{l}\mathbf{A}_{1} \mathbf{B}_{1} \\
\mathbf{A}_{2} \mathbf{B}_{1}\end{array}$ & $\begin{array}{l}3,75 \\
5,94\end{array}$ & 0,63 & 3,44 & Homogen \\
\hline $\begin{array}{l}\mathbf{A}_{1} \mathbf{B}_{2} \\
\mathbf{A}_{2} \mathbf{B}_{2}\end{array}$ & $\begin{array}{l}3,44 \\
5,44\end{array}$ & 0,63 & 3,44 & Homogen \\
\hline
\end{tabular}


Hasil perhitungan uji homogenitas varians sebagaimana terlihat pada Tabel

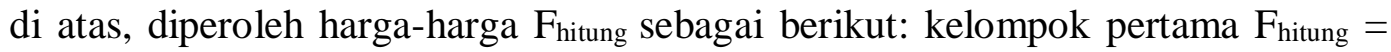
2,25 ; kelompok kedua $F_{\text {hitung }}=2,09$; kelompok ketiga $F_{\text {hitung }}=0,63$; kelompok keempat $F_{\text {hitung }}=0,63$, sedangkan $F_{\text {tabel }}=2,27$ untuk kelompuk pertama dan kedua. dan $\mathrm{F}_{\text {tabel }}$ 3,44 untuk kelompok ketiga dan ke empat. Dengan demikian $F_{\text {hitung }}$ semua kelompok lebih kecil dari pada $\mathrm{F}_{\text {tabel }}\left(\mathrm{F}_{1234}<\mathrm{F}_{\text {tabel }}\right)$. Dengan kata lain sampel berasal dari populasi yang homogen.

Setelah uji persyaratan analisis terpenuhi, selanjutnya dilakukan pengujian hipotesis statistic dengan menggunakan Analisis Varians (ANAVA) dua jalur, pada taraf signifikansi $\alpha=0,05$, dilanjutkan dengan uji Tukey.

Tabel 6. Rangkuman Hasil Perhitungan Analisis Varians (ANAVA) Dua jalurData Hasil Belajar Shooting

\begin{tabular}{|l|c|c|c|c|c|}
\hline \multicolumn{1}{|c|}{ Sumber Varians } & \multirow{2}{*}{ JK } & \multirow{2}{*}{ Dk } & \multirow{2}{*}{ RJK } & \multirow{2}{*}{$\boldsymbol{F}_{\text {hitung }}$} & $\boldsymbol{F}_{\text {tabel }}$ \\
\cline { 5 - 7 } & & & & $\boldsymbol{\alpha}=\mathbf{0 , 0 5}$ \\
\hline Antar Baris (b) & 90,250 & 1 & 90,25 & 19,42 & 4,08 \\
Antar Kolom (k) & 23,361 & 1 & 23,3611 & 5,02 & 4,08 \\
Interaksi (bxk) & 61 & 1 & 61,3611 & 13,20 & 4,08 \\
Dalam Kelompok (DK) & 148,67 & 32 & 4,6458 & & 4,08 \\
\hline \multicolumn{1}{|c|}{ Total } & 323,64 & 35 & - & - & - \\
\hline
\end{tabular}

\section{PEMBAHASAN}

1. Terdapat Perbedaan Hasil Belajar Shooting Sepakbola Antara yang Diajar dengan Gaya Mengajar Inklusi dan yang Diajar dengan Gaya Mengajar Latihan Secara Keseluruhan.

Dari hasil perhitungan analisis varians (ANAVA) diperoleh harga $F_{\text {hitung }}=$ 19,42 sedangkan harga $F_{\text {tabel }}$ dengan dk pembilang $\mathrm{V}_{1}(\mathrm{a}-1)(\mathrm{b}-1)=(2-1)(2-1)=1$, $\mathrm{dk}$ penyebut $\mathrm{V}_{2} \mathrm{ab}(\mathrm{n}-1)=2 \times 2(18-1)$, pada taraf signifikansi $\alpha=0,05$ sebesar 4,08. Dengan demikian $F_{\text {hitung }}>F_{\text {tabel }}\left(F_{\text {hitung }}=19,42>F_{\text {tabel }}=4,08\right)$. Sehingga $H_{o}$ ditolak $\left(F_{0}>F_{t}\right)$ ini menunjukkan bahwa secara keseluruhan terdapat perbedaan hasil belajar shooting atas secara berarti antara siswa yang diajar dengan menggunakan gaya mengajar inklusi dan siswa yang diajar dengan menggunakan gaya mengajar latihan. Secara keseluruhan kelompok yang diajar dengan 
$\overline{\text { menggunakan gaya mengajar inklusi lebih baik dibandingkan dengan kelompok }}$ yang diajar dengan menggunakan gaya mengajar latihan. Hal ini karena skor rerata kelompok gaya mengajar inklusi adalah $\mathrm{x}=22,11$ dan $\mathrm{s}=3,49$, sedangkan rerata skor kelompok gaya mengajar latihan adalah $\mathrm{x}=20,5$ dan $\mathrm{s}=2,33$

\section{Terdapat Interaksi antara Gaya Mengajar dan Percaya diri terhadap Hasil Belajar Shooting Sepakbola}

Dari hasil perhitungan analisis varians (ANAVA) dua jalur diperoleh $F_{\text {hitung }}$ $=13,20$ dan $\mathrm{F}_{\text {tabel }}$ dengan dk pembilang $\mathrm{V}_{1}(\mathrm{a}-1)=1$, dk penyebut $\mathrm{V}_{2} \mathrm{ab}(\mathrm{n}-1)=2$ $X 2(18-1)=17$ pada taraf signifikan $\alpha=0,05$ sebesar 4,08. Dengan demikian $H_{o}$ ditolak $\left(\mathrm{F}_{\mathrm{h}}>\mathrm{F}_{\mathrm{t}}\right)$, ini artinya terdapat pengaruh interaksi yang sangat berarti antara gaya mengajar dan percaya diri yang dimiliki siswa terhadap hasil belajar shooting.

3. Perbedaan Hasil Belajar Shooting Sepakbola antara Kelompok Siswa yang Diajar Gaya Mengajar Inklusi dan yang Diajar dengan Gaya Mengajar Latihan, Bagi Siswa yang Memiliki Percaya diri Tingggi

Ditinjau dari data penelitian menggunakan uji Tukey di atas diperoleh $\mathrm{Q}_{\text {hitung }}=4,48$ lebih besar dari pada $\mathrm{Q}$ tabel $=3,86$ ( $\mathrm{Q}$ hitung $=4,48>\mathrm{Q}$ tabel $=$ 3,86 ) sehingga $H_{o}$ ditolak $\left(F_{0}>F_{t}\right)$, ini berarti perbedaan yang signifikan hasil belajar shooting sepakbola bagi siswa yang memiliki percaya diri tinggi yang diajar dengan gaya mengajar inklusi dan yang diajar dengan gaya mengajar latihan. Artinya terdapat perbedaan yang sangat berarti hasil belajar shooting antara siswa yang diajar dengan gaya mengajar inklusi dan yang diajar dengan gaya mengajar latihan, bagi siswa yang memiliki percaya diri tinggi.Gaya mengajar inklusi $(\mathrm{x}=25, \mathrm{~s}=1,93)$ lebih baik dari pada gaya mengajar latihan $(\mathrm{x}=$ 20,77, s = 2,43) bagi siswa yang memiliki percaya diri tinggi.

4. Perbedaan Hasil Belajar Shooting Sepakbola antara Kelompok Siswa yang Diajar Gaya Mengajar Inklusi dan yang Diajar dengan Gaya Mengajar Latihan, Bagi Siswa yang Memiliki Percaya diri Rendah

Ditinjau dari data penelitian menggunakan uji Tukey di atas diperoleh $Q_{\text {hitung }}=$ 11,75 lebih besar dari pada $\mathrm{Q}$ tabel $=3,86\left(\mathrm{Q}_{\text {hitung }}=11,75>\mathrm{Q}\right.$ tabel $\left.=3,86\right)$. Sehingga $\mathrm{H}_{\mathrm{o}}$ ditolak $\left(\mathrm{F}_{0}>\mathrm{F}_{\mathrm{t}}\right)$, ini berarti perbedaan yang signifikan hasil belajar shooting bagi siswa yang memiliki percaya diri rendah yang diajar dengan gaya 
mengajar latihan dan yang diajar dengan gaya mengajar inklusi. Artinya terdapat perbedaan yang sangat berarti hasil belajar shooting antara siswa yang diajar dengan gaya mengajar latihan dan yang diajar dengan gaya mengajar inklusi, bagi siswa yang memiliki percaya diri rendah. Gaya mengajar latihan $(\mathrm{x}=19,22, \mathrm{~s}=$ $1,85)$ lebih baik daripada gaya mengajar inklusi $(\mathrm{x}=20,22, \mathrm{~s}=2,33)$ bagi siswa yang memiliki percaya diri rendah.

\section{KESIMPULAN}

Pembelajaran dengan gaya mengajar inklusi sangat bermanfaat dalam pengajaran motorik.Dalam gaya mengajar inklusi selama kegiatan berlangsung,siswadiarahkan secarabaik mulai dari berdoa, absen kelas, pemanasan (warming up), gerakan dasar, hingga gerakan yang benar yang diamati sehingga terdapat perbaikan dalam melakukan tugas-tugas motorik adalah mengenai hasil pembelajaran yang diperoleh, sehingga semakin besar kemungkinan mencapai sebuah hasil yang diharapkan.

Hasil temuan dari penelitian yang dilakukan sebagaimana dikemukakan pada kesimpulan di atas menunjukkan bahwa terdapat pengaruh interaksi antara gaya mengajar dengan percaya diri terhadap hasil belajarshooting sepakbola. Setelah ditemukannya pengaruh interaksi ini, dapat diartikan bahwa kedua gaya mengajar memberikan pengaruh yang berbeda terhadap hasil belajarshooting sepakbola. Kita kaitkan dengan hasil belajarshooting sepakbola, pada kelompok siswa yang memiliki percaya diri tinggi ternyata gaya mengajar inklusi lebih tinggi hasilnya dibandingkan gaya mengajar latihan, sedangkan pada kelompok siswa yang memiliki percaya diri rendah, gaya mengajar latihan lebih tinggi nilainya dibandingkan gaya mengajar inklusi. 


\section{DAFTAR PUSTAKA}

A.Coker, Cheryl. 2004. Motor Learning And Control For Practitioners. Mexico: Mcgraw Hill.

Adam, Usman, Tina Wijaya. 2007. Dasar-Dasar Mengejar Sepakbola. Jakarta: Cerdas Jaya.

Al-Hadiqie, Zidane Muhdhor. 2013. Menjadi Pemain Sepakbola Profesional. Jakarta: Kata Pena.

Ardo Okilanda, Firmansyah Dlis, Hidayat Humaid, D. D. P. (2020). Jurnal Educatio FKIP UNMA. Ejournal.Unma.Ac.Id, 6(2), 548-560. https://doi.org/10.31949/educatio.v6i2.594

Arsil, dkk. 2011. Permainan Sepakbola. Padang: UNP Press.

Critchell,Mick. 2003. Warm Ups for Soccer A Dynamic Approach.Michigan: Reedswain Publishing.

Kadir. 2010. Statistik Untuk Penelitian Ilmu-Ilmu Sosial dilengkapi dengan Output Program SPSS. Jakarta: Rosemata Sampurna.

Koger,Robert. 2007. Latihan Dasar Andal Sepakbola Remaja. Klaten: PT Saka Mitra Kompetensi.

Luxbacher,Joseph A. 2013. Sepakbola Edisi Kedua. Jakarta: PT. Raja Grafindo Persada.

Okilanda, Ardo., Dony, Pria Roma., \& Putra, D. D. (2020). Berlatih Sepakbola. Zenius.

Okilanda, A. (2017). Analisis Pembelajaran Gerak Keterampilan ....( Ardo Okilanda). 7, 31-41.

Suharno. 2000. Metodologi Pelatihan. Jakarta: KONI Pusat.

Sugiyono. 2010. Metode Penelitian Pendidikan Pendekatan Kuatitatif, Kualitatif, dan $R \& D$. Bandung: Alfabeta.

Syahrastani. 2010. Psikologi Olahraga. Padang: Wineka Media.

Uno,Hamzah B. 2008. Teori Motivasi dan Pengukurannya.Jakarta: Bumi Aksara. 